\title{
Evaluation of Pretreatment Methods (Acid and Alkali) in Improving the Enzymatic Saccharification of Sugarcane Baggase: Structural and Chemical Analysis
}

\section{Soni Tiwari}

Banaras Hindu University

Janardan Yadav ( $\sim$ janardanbhu@gmail.com )

Banaras Hindu University

Rajeeva Gaur

Dr Ram Manohar Lohia Avadh University

Jay Shanker Yadav

Banaras Hindu University

\section{Research}

Keywords: Sugar cane bagasse, acid and alkali pretreatment, SEM microscopy, XRD and FTIR spectroscopy

Posted Date: July 22nd, 2020

DOI: https://doi.org/10.21203/rs.3.rs-45870/v1

License: (c) (i) This work is licensed under a Creative Commons Attribution 4.0 International License.

Read Full License 


\section{Abstract}

Background: Enhancement of cellulase and xylanase production and improvement of more proficient lignocellulose-degrading enzymes are essential in order to decrease the price of enzymes required in the biomass-to-bioethanol production.

Results: The effectiveness of different concentration of alkali and acid pretreatment of sugarcane bagasse for improving the enzymatic saccharification of cellulose has been evaluated. The sugarcane bagasse was characterized to contain $39.52 \%$ cellulose, $25.63 \%$ hemicelluloses, $30.36 \%$ lignin, $1.44 \%$ ash and $2.90 \%$ other extractives. Afterthat, The sugarcane bagasse was pretreated with two different concentrations (5\% and $10 \%$ ) of $\mathrm{H}_{2} \mathrm{SO}_{4}$ and $\mathrm{NaOH}$ at $121^{\circ} \mathrm{C}$ for 60 min. Among them, the best result was obtained when sugarcane bagasse was pretreated with $10 \% \mathrm{NaOH}$ solution followed by $10 \% \mathrm{H}_{2} \mathrm{SO}_{4}, 5 \%$ $\mathrm{NaOH}$ and $5 \% \mathrm{H}_{2} \mathrm{SO}_{4}$ solution. The highest cellulose saccharification was $489.5 \mathrm{mg} / \mathrm{g}$ from $10 \% \mathrm{NaOH}$ pretreatment followed by $322.75 \mathrm{mg} / \mathrm{g}, 301.25 \mathrm{mg} / \mathrm{g}$ and $276.6 \mathrm{mg} / \mathrm{g}$ from $10 \% \mathrm{H}_{2} \mathrm{SO}_{4}, 5 \% \mathrm{NaOH}$ and $5 \%$ $\mathrm{H}_{2} \mathrm{SO}_{4}$, respectively, which were 55.1, 32.0, 27.1 and 20.6 times higher than the control. Moreover, the FTIR, XRD and SEM analysis showed significant molecule and surface structure changes of the sugarcane bagasse after different pretreatments. Cellulase and xylanase produced by Pseudomonas sp. CVB-10 [MK443365] and Bacillus paramycoides T4 [MN370035] was used to hydrolyze the pretreated sugarcane bagasse and the optimal condition was determined to be $30 \mathrm{~h}$ of enzymatic reaction with 3:1 ration of enzymes under the temperature of $55^{\circ} \mathrm{C}, \mathrm{pH} 5.5$, substrate concentration of $3 \%$ and Tween-20 $0.5 \%$. Conclusion: Enzyme supernatants produced by the mixed culture of Pseudomonas sp. CVB-10 [MK443365] and Bacillus paramycoides T4 [MN370035] on various pretreated sugarcane baggase have good cellulase and xylanase activities, leading to celluloses and Hemicelluloses conversion in the enzymatic hydrolysis/saccharification that is more proficient.

\section{Background}

Sugarcane is one of the most popular crops in India with more than 5 million hectares of land under cultivation. The average yield of sugarcane is more than $75000 \mathrm{~kg} /$ hectare with the total production exceeding 360 million tonnes and 110 million ton of bagasse, a solid waste resulting from juice extraction in 2019. Uttar Pradesh has the largest cultivable land of around 21 lakh hectares with an annual output of 133.3 million tonnes. Uttar Pradesh stands proudly at the top of the list, second and third largest states are Maharashtra and Karnataka. India hold the second rank in the world after Brazil as far as sugarcane production is concerned.

Sugar industries generated a bulk amount of sugarcane bagasse from sugarcane as a by-product [1], during glucose, xylose, ethanol and methane production as a alternate energy to gasoline has been widely practiced in industry, by virtue of the pronounced fluctuation and increase in oil value, greenhouse gas emissions, global warming and big demand of petroleum from some developing countries [2-3]. A part of sugarcane bagasse was used for electricity production and the remaining 16 million tons of dry bagasse have no direct application. The generation of bioethanol can decrease the import of petroleum 
and, thereby, increase the autonomy of energy growth in a country (energy security), such as the United State and Brazil [4-5].

The sugarcane bagasse is, as any lignocellulosic material, mostly constituted by cellulose, hemicellulose and lignin. These three components amount to more than $90 \%$ of the dry weight of the fiber. The predominant component of sugarcane bagasse biomass is cellulose, derived from D-glucose units, which condense through $\beta(1 \rightarrow 4)$-glycosidic bonds. It is non-toxic, renewable, biodegradable, modifiable and has great potential as an excellent industrial material [6-7]. Cellulose consists of fibrils with crystalline and amorphous regions. hemicelluloses can include the five-carbon sugars xylose and arabinose, the sixcarbon sugars mannose and galactose, and the six-carbon deoxy sugar rhamnose. lignin comprises about $1 / 3$ of the mass of lignocellulose after cellulose and hemicellulose.

Various technologies have adopted to improve the bioconversion of these substrates into bioethanol [810]. Enzymatic saccharification is one of the prominent approaches to alter cellulosic biomass into sugars because of low energy constraint and less pollution. Due to the recalcitrant structure of lignocelluloses, a pretreatment step is required prior to enzymatic saccharification in order to make the cellulose more accessible to the enzymes $[11,9]$. The main aim of various pretreatment methods is to eliminate the lignin content and to reduce the cellulose crystallinity [1 2]. Although various physical (comminution, hydro-thermolysis), chemical (acid, alkali, solvents, ozone), and biological pretreatment methods have been examined over the years [13-16].

In acid-catalyzed pretreatment, the major part of the hemicellulose is degraded, and the cellulose has to be hydrolyzed by the use of cellulases. Alkaline pretreatment is basically a delignification process, in which a significant amount of hemicellulose is solubilized as well. The action mechanism is believed to be saponification of Intermolecular ester bonds cross linking xylan hemicelluloses and other components, for example, lignin and other hemicellulose. Alkaline pretreatment also removes acetyl and various uronic acid substitutions on hemicellulose that reduce the accessibility of hemicellulose and cellulose to enzymes [17].

Several workers have been studied different properties of the solid part of acid and alkali pretreated sugarcane bagasse. The crystallinity of the cellulose segment (X-Ray Diffraction), the organic groups that comprise the biomass (FTIR) and Exterior morphology (SEM) have been observed. Different morphological studies with different biomass like soybean straw, wheat bran, and rice hulls have also been approved after different pretreatments [18-21].

The main aim of this study was to apply strong acid and alkali pretreatments of sugarcane bagasse and analyze the chemical composition, Crl (crystallinity index), SEM, FTIR analysis of pretreated bagasse with the outcome find for glucose generation by enzymatic saccharification/hydrolysis.

\section{Results}

\section{Chemical analysis}


Indigenous Sugarcane Bagasse was applied for chemical composition analysis and found that Sugarcane Bagasse contains cellulose (39.52\%), hemicellulose (25.63\%), total lignin (30.36\%), ash (1.44\%), and extractives (2.90\%) (Table 1). The compositional analysis of the un-treated and the pretreated bagasse samples showed that after alkaline pretreatment the proportion of cellulose and hemicellulose increased by 33 and $27 \%$, respectively, while lignin decreased by $44 \%$. Hence, degradation of lignin may assist the action of cellulases and hemicellulases enzymes on cellulose and hemicellulose, respectively. Hydrolysis of hemicellulose and cellulose in alkaline pretreatment is less when compared with acid treated samples. Though, the pretreatment process is necessary for enzymatic competence during saccharification process.

Table 1

Compositional analyses of the raw, acid and alkali pretreated sugarcane bagasse (SCB)

\begin{tabular}{|lllll|}
\hline S.N. & Components & \multicolumn{3}{l|}{ Composition of sugarcane bagasse biomass (\%) } \\
\cline { 3 - 5 } & & Raw & Acid Treated & Alkali Treated \\
\hline 1 & Cellulose & $39.52 \pm 0.66$ & $45.30 \pm 0.45$ & $52.4 \pm 0.21$ \\
\hline 2 & Hemicellulose & $25.63 \pm 0.44$ & $14.50 \pm 0.37$ & $26.3 \pm 0.19$ \\
\hline 3 & Acid insoluble lignin & $26.40 \pm 0.02$ & $27.70 \pm 0.50$ & $10.9 \pm 0.30$ \\
\hline 4 & Acid soluble lignin & $3.60 \pm 0.90$ & $4.10 \pm 0.61$ & $7.0 \pm 0.50$ \\
\hline 5 & Total Lignin & $30.36 \pm 0.13$ & $31.50 \pm 0.33$ & $17.1 \pm 0.37$ \\
\hline 6 & Organic solvent extract & $1.72 \pm 0.16$ & $1.28 \pm 0.23$ & $0.91 \pm 0.36$ \\
\hline 7 & Hot water extract & $1.32 \pm 0.17$ & $7.52 \pm 0.34$ & $5.97 \pm 0.17$ \\
\hline 8 & Ash & $1.45 \pm 0.21$ & $1.50 \pm 0.21$ & $1.0 \pm 0.29$ \\
\hline 9 & Total & 100.00 & 101.40 & 103.68 \\
\hline The amounts of cellulose, hemicellulose, lignin, and ash are based on dry weight \\
\hline
\end{tabular}

\section{Structural characterization}

\section{Fourier transforms infrared (FTIR) spectroscopy}

The chemical structure of untreated and pretreated bagasse samples was analyzed by using FTIR. From Fig. 1 , it clear that the spectra produced for samples pretreated by acid $\left(5 \%\right.$ and $10 \% \mathrm{H}_{2} \mathrm{SO}_{4}$ at $121^{\circ} \mathrm{C}$ for $60 \mathrm{~min}$ ) and alkali ( $5 \%$ and $10 \% \mathrm{NaOH}$ at $121^{\circ} \mathrm{C}$ for $60 \mathrm{~min}$ ) were some major differences observed to that of the un-treated sugarcane bagasse. In this experiment, the absorbency of $897 \mathrm{~cm}^{-1}$ was observed more intense in cases of acid-pretreated sugarcane bagasse then alkali-pretreated sugarcane bagasse and un-treated sample. Result indicate that the presence of amorphous cellulose, the band at $897 \mathrm{~cm}^{-1}$, which distinguish the $\mathrm{C}-\mathrm{O}-\mathrm{C}$ stretching at $\beta-1,4-$ glycosidic linkage, is burly and sharp. 
The band at 1053 to $1060 \mathrm{~cm}-1$ shows the disordered crystalline region for untreated and pretreated sugarcane bagasse samples. The absorbencies of $1250-1263 \mathrm{~cm}^{-1}$ (C-C) was more intense in the acid pretreated ( $5 \%$ and $10 \% \mathrm{H}_{2} \mathrm{SO}_{4}$ at $121^{\circ} \mathrm{C}$ for $60 \mathrm{~min}$ ) and un-treated sugarcane bagasse and depart in alkali pretreated $\left(5 \%\right.$ and $10 \% \mathrm{NaOH}$ at $121^{\circ} \mathrm{C}$ for $60 \mathrm{~min}$ ) sample, although the peak at $1202 \mathrm{~cm}^{-1}$ (C-0 and $C=0$ stretching) was more strong in the acid pretreatments. The bonds at $1,375,1,162$, and $1,055 \mathrm{~cm}^{-1}$ were weaker for acid and alkali pretreated samples compared to the raw sample.

The band $1,425 \mathrm{~cm}^{-1}$ is intens e in crystalline cellulose and fragile in amorphous cellulose. Therefore, elevated crystalline cellulose find in $5 \& 10 \% \mathrm{H}_{2} \mathrm{SO}_{4}, 5 \% \mathrm{NaOH}$ and un-treated sugarcane bagasse when compared with the $10 \% \mathrm{NaOH}$ treated sample. On the other hand, cellulose in sugarcane bagasse turns into more amorphous later than pretreatment with strong alkali. It could be concluded that the amount of amorphous cellulose was highest in the sugarcane bagasse sample pretreated by $10 \% \mathrm{NaOH}$ followed by $5 \%, 10 \% \mathrm{H}_{2} \mathrm{SO}_{4}$ and $5 \% \mathrm{NaOH}$, respectively.

Figure 1, clearly indicate that when samples pretreated with acid were delignified to some extent for the bonds produced at $1,324,1,514$ and $1604 \mathrm{~cm}^{-1}$ were identical and that there was a subtle difference between the acid pretreated samples and the untreated one. On the other hand, peak disappear at 1,324, 1,514 and $1604 \mathrm{~cm}^{-1}$ when sugarcane pretreated with alkali was delignified more proficiently when comparison with the acid pretreatments and un-treated sugarcane bagasse. The FTIR analysis of bagasse further showed an aldehyde group absorption peak was clearly present at $1733 \mathrm{~cm}^{-1}$. It was observed that, the absorption peak at $1733 \mathrm{~cm}^{-1}$ was disappearance when the sugarcane bagasse treated with acid and alkali pretreatment.

The peak at $3395 \mathrm{~cm}^{-1}(\mathrm{O}-\mathrm{H})$ was more strong in the acid pretreatment $\left(5 \%\right.$ and $10 \% \mathrm{H}_{2} \mathrm{SO}_{4}$ at $121^{\circ} \mathrm{C}$ for $60 \mathrm{~min})$ than in the alkaline pretreatment $\left(5 \%\right.$ and $10 \% \mathrm{NaOH}$ at $121^{\circ} \mathrm{C}$ for $\left.60 \mathrm{~min}\right)$ and in untreated sugarcane bagasse. A similarity in the bands at $2917 \mathrm{~cm}^{-1}$ could be observed for the raw material, acid and the alkaline pretreatment, but was more intense for the acid pretreatments. The results indicated that the highly crystalline cellulose in sugarcane bagasse was transformed to amorphous form after pretreatment. Overall as could be concluded from Fig. 1, using alkali pretreatments is a suitable method for removing lignin.

\section{X-RAY Diffraction}

X-ray diffraction (XRD) investigation carried out to assess the crystallinity degree of the un-treated and pretreated bagasse. The XRD analysis of untreated bagasse, acid $\left(5 \%\right.$ and $10 \% \mathrm{H}_{2} \mathrm{SO}_{4}$ at $121^{\circ} \mathrm{C}$ for $60 \mathrm{~min}$ ) pretreated bagasse (cellulignin), and alkali ( $5 \%$ and $10 \% \mathrm{NaOH}$ at $121^{\circ} \mathrm{C}$ for $60 \mathrm{~min}$ ) pretreated cellulignin substrate is presented in Fig. 2a-e. The intensities (1002) of the amorphous cellulose peak and crystalline cellulose peak were considered to calculate the Crystallinity Index (Crl) of all five samples of bagasse. The $\mathrm{Crl}$ of untreated bagasse was $49.67 \%$, which was close to a previously available report (Table 1). The $\mathrm{Crl}$ of acid and alkali pretreated sugarcane bagasse was comparatively lower than untreated sugarcane bagasse showing the sequential increment in cellulose content in these samples 
(Fig. $2 \mathrm{~b}, \mathrm{c}, \mathrm{d}, \mathrm{e})$. Acid pretreatment of bagasse $\left(5 \%\right.$ and $10 \% \mathrm{H}_{2} \mathrm{SO}_{4}$ at $121^{\circ} \mathrm{C}$ for $60 \mathrm{~min}$ ) removed the hemicellulose, and thus increased the cellulose amount in samples eventually and showed lower $\mathrm{Crl}$ (35.7 and $33.97 \%)$. Further, cellulignin when pretreated with alkali pretreatment $\left(5 \%\right.$ and $10 \% \mathrm{NaOH}$ at $121^{\circ} \mathrm{C}$ for $60 \mathrm{~min}$ ) showed lower $\mathrm{Crl}$ (41.1 and 11.2\%) because of the removal of lignin, and thus increased the cellulose concentration in bagasse than that of untreated sugarcane bagasse and cellulignin.

\section{Scanning electron microscopy (SEM)}

Scanning electron microscopy analyzed external structural alterations occurred in pretreated sugarcane bagasse by different concentration of acid ( 5 and $10 \% \mathrm{H}_{2} \mathrm{SO}_{4}$ at $121^{\circ} \mathrm{C}$ for $60 \mathrm{~min}$ ) and alkaline (5 and $10 \% \mathrm{NaOH}$ at $121^{\circ} \mathrm{C}$ for $60 \mathrm{~min}$ ). SEM images of un-treated, acid and alkali pretreated sugarcane bagasse samples were taken at different magnifications. The untreated sugarcane bagasse had highly compact, ordered and rigid fibril morphology (Fig. 3a) when compared with acid and alkali pretreated bagasse samples (Fig. 3b-e). Alkali-pretreated bagasse sample (10\% $\mathrm{NaOH}$ at $121^{\circ} \mathrm{C}$ for $\left.60 \mathrm{~min}\right)$ was harshly disrupted followed by $5 \% \mathrm{NaOH}$ alkali, $10 \% \mathrm{H}_{2} \mathrm{SO}_{4}$ and $5 \% \mathrm{H}_{2} \mathrm{SO}_{4}$ acid-pretreatments. On other hands, acid (5\% and $10 \% \mathrm{H}_{2} \mathrm{SO}_{4}$ at $121^{\circ} \mathrm{C}$ for $60 \mathrm{~min}$ ) and alkali (5\% $\mathrm{NaOH}$ at $121^{\circ} \mathrm{C}$ for $60 \mathrm{~min}$ ) pretreatments had some little dissimilarly effects on sugarcane bagasse (Fig. 3b-e).

\section{Enzymatic hydrolysis}

Enzymatic hydrolysis of pretreated sugarcane bagasse was carried out by using cellulase and xylanase filtrate of Pseudomonas sp. CVB-10 and Bacillus paramycoides T4. Five different type processed bagasse (Un-treated sugarcane bagasse, $5 \% \& 10 \% \mathrm{NaOH}$ at $121^{\circ} \mathrm{C}$ for $60 \mathrm{~min}$ and $5 \% \& 10 \% \mathrm{HCl}$ at $121^{\circ} \mathrm{C}$ for 60 min treated bagasse) were used for enzymatic saccharification. The various parameters such as hydrolysis time, substrate concentration, temperature, $\mathrm{pH}$, enzyme ratio and different concentration of tween-20 were optimized to achieve maximum saccharification of bagasse. All data is graphically represented in (Fig. 4a-f).

The effect of enzymatic reaction time influences saccharification/hydrolysis of the un-treated and pretreated sugarcane baggasse. From result it clear that, the concentration of the released reducing sugars was increased, as the reaction time was increased (Fig. 4a). A maximum of $430.95 \mathrm{mg} / \mathrm{g}$ reducing sugars with a maximal saccharification was obtained from $10 \% \mathrm{NaOH}$ at $121{ }^{\circ} \mathrm{C}$ followed by $10 \% \mathrm{H}_{2} \mathrm{SO}_{4}$ $(309.9 \mathrm{mg} / \mathrm{g}), 5 \% \mathrm{NaOH}(289.6 \mathrm{mg} / \mathrm{g}) \& 5 \% \mathrm{H}_{2} \mathrm{SO}_{4}(250.67 \mathrm{mg} / \mathrm{g})$ at $121^{\circ} \mathrm{C} 30 \mathrm{~h}$ of enzymatic hydrolysis. The content of reducing sugar was gradually decreased after $30 \mathrm{~h}$ of incubation. This might be due to the inhibition of the enzyme activity by the accumulated hydrolysis products.

The effect of substrate concentration on enzyme saccharification/hydrolysis was determined by using $1.0 \%-8.0 \%$ of un-treated and pretreated sugarcane bagasse under optimized parameters. The results showed that the maximum $450.78 \mathrm{mg} / \mathrm{g}$ reducing sugar with maximum saccharification was achieved at $5 \%$ substrate concentration (10\% alkali pretreated sugarcane bagasse) within $30 \mathrm{~h}$ (Fig. 4b). Above and below of this substrate concentration, enzymatic saccharfication rate and hydrolysis rate were decreased gradually. 
Temperature is an important factor, which influences not only the enzymatic reaction, but also the activity of the cellulase and xylanase. Generally, as the temperature is raised in a certain range, the enzymatic activity is accelerated. Enzyme catalyzed reaction like most chemical reactions; proceeds at a faster velocity as the temperature is increased. The optimal reaction temperature for cellulase and xylanase is between $45^{\circ} \mathrm{C}-55^{\circ} \mathrm{C}$. In this experiment, maximum reducing sugars $(456.87 \mathrm{mg} / \mathrm{g}$ substrate) with maximum saccharification rate was observed at $55^{\circ} \mathrm{C}$ from alkali pretreated sugarcane bagasse $(10 \%)$ (Fig. 4c). Further increased temperature beyond $55^{\circ} \mathrm{C}$, the concentration of reducing sugar and saccharification rate were reduced. Thus, the optimal temperature for enzymatic saccharification/hydrolysis was $55^{\circ} \mathrm{C}$.

The enzymatic saccharification/hydrolysis was also affected by their initial $\mathrm{pH}$ conditions. Figure $4 \mathrm{~d}$ depicted that maximum reducing sugars $(470.03 \mathrm{mg} / \mathrm{g}$ ) with maximum saccharification were achieved at $\mathrm{pH} 5.0$ from alkali pretreated SB. When $\mathrm{pH}$ was increased or decreased than 5.0 , the enzymatic reaction was reduced.

Enzyme ratio also influences enzymatic saccharification/hydrolysis of pretreated sugarcane bagasse. Figure 4(e) depicts the different enzyme ratios on the enzymatic saccharification/hydrolysis of all five samples. Different range of enzyme ratio (cellulase: xylanase); 1:1, 1:2, 1:3, 2:1 and 3:1, were used. The highest amount of reducing sugar $476.9 \mathrm{mg} / \mathrm{g}$ with maximum saccharification was obtained after $30 \mathrm{~h}$ reaction when enzyme ratio was at 3:1. It was then followed by the enzyme ratio 2:1, 1:3, 1:2 and 1:1. The findings illustrated that the enzyme ratio of 2:1 and 3:1 produced higher amounts of reducing sugar compared others.

Surfactant also influences the enzymatic hydrolysis at different concentrations by increasing the surface area of the substrate. In this experiment different concentration (0.1-1.0\%) of tween-20 were optimized for maximum saccharification under all optimized conditions. Figures (4f) depicted that maximum $489.50 \mathrm{mg} / \mathrm{g}$ reducing sugar with maximum saccharification rate was achieved at $0.5 \%$ tween-20 concentration. Above and below this concentration there is no significant result was reported from the surfactant. Surfactants generally enhance the surface area of lignocellulosic substrates to improve the extent of enzymatic hydrolysis.

\section{Discussion}

During chemical composition analysis of sugarcane bagasse was found that it contain cellulose (39.52\%), hemicellulose (25.63\%), total lignin (30.36\%), ash (1.44\%), and extractives (2.90\%) (Table 1). Similar results were reported by several other workers [14, 22-23]. The composition of sugarcane bagasse fluctuates with variety, origin, cultivation type of sugarcane, and the analytical method used for the characterization [24, 14]. In contrast to our result, Moretti et al., [25] observed $46.9 \%$ cellulose, $16.3 \%$ hemicellulose, $27.1 \%$ lignin, and $2.0 \%$ ash in sugarcane bagasse. Lamounier et al.,[26] observed $54.4 \%$ cellulose, $13.5 \%$ hemicellulose, $26.1 \%$ total lignin, and $0.6 \%$ ash in sugarcane bagasse. 
In the chemical analysis, it was found that after alkaline pretreatment the proportion of cellulose and hemicellulose increased by 33 and $27 \%$, respectively, while lignin decreased by $44 \%$. Lamounier et al., [26] also reported that after alkali pretreatment, lignin content of sugarcane bagasse was decreased by $43 \%$. These results were previously predictable, because alkali works primarily on lignin, promoting its degradation. Lignin is considered a barrier that confines the access of essential enzymes for saccharification [27, 22]. Hence, degradation of lignin may assist the action of cellulases and hemicellulases enzymes on cellulose and hemicellulose, respectively. Hydrolysis of hemicellulose and cellulose in alkaline pretreatment is less when compared with acid treated samples [28, 26]. From the above results it clear that, observed data are in agreement with text which reports that alkaline pretreatment preferentially removes lignin $[29,26]$, and acid pretreatment degrades hemicellulose fraction $[30,22]$. Though, the pretreatment process is necessary for enzymatic competence during saccharification process.

The chemical structure of untreated and pretreated sugarcane bagsse samples was analyzed by using FTIR. As shown in Fig. 1, the spectra generated for samples pretreated by acid and alkali was different to that of the un-treated sugarcane bagasse; however, there were some major differences observed. For instance, at $897 \mathrm{~cm}^{-1}$, the peak obtained was more intense in cases of acid-pretreated sugarcane bagasase compared with untreated and alkali-pretreated sample. In the presence of amorphous cellulose, the band at $897 \mathrm{~cm}^{-1}$, which characterizes the $\mathrm{C}-0-\mathrm{C}$ stretching at $\beta-1,4-g l y c o s i d i c$ linkage, is strong and sharp [31, 32]. The intensity of the regenerated cellulose band is relatively stronger than that of the original cellulose. It has been reported that the intensity of this peak increases with a decrease in the crystallinity of the cellulose sample and a change in the crystal lattice from cellulose I to cellulose II [33]. These observations indicated that the regenerated cellulose has lower crystallinity, and the pretreatment led to the conversion of the crystalline structure of the original cellulose from cellulose I to cellulose II.

Disruption of the crystalline region of raw and pretreated sugarcane bagasse samples was observed at the absorbencies of 1053 to $1060 \mathrm{~cm}^{-1}$. These peaks represent the shattering of hydrogen bond in pretreated sugarcane bagasse samples $[34,15]$. The absorbency range between $1250-1263 \mathrm{~cm}^{-1}$ (C-C) was stronger in the acid pretreated and un-treated sugarcane bagasse and disappears in alkali pretreated bagasse sample. Disappearance of these band represents that lignin was partially or effectively removed after alkali pretreatment [15] although the peak at $1202 \mathrm{~cm}^{-1}$ (C-O and $\mathrm{C}=0$ stretching) was more intense in the acid pretreatments. Guilherme et al., [35] also reported similar observation regarding those peaks after bagasse pretreatment.

In addition, the broad band at $1375 \mathrm{~cm}^{-1}$ due to phenolic hydroxyl group [36-37]. The mean value for the relative absorbance of phenolic hydroxyl groups was reduced for pretreated bagasse [37]. The peaks at $1,375,1,162$, and $1,055 \mathrm{~cm}^{-1}$ are specifically attributed to $\mathrm{C}-\mathrm{H}$ bending vibration, $\mathrm{C}-\mathrm{O}-\mathrm{C}$ asymmetric bridge stretching vibration and $\mathrm{C}-\mathrm{O}$ stretching vibration in cellulose and hemicellulose, respectively [3839]. These peaks were weaker for acid and alkali pretreated samples compared to the untreated sample. 
The peak $1,425 \mathrm{~cm}^{-1}$ can be assigned to bending vibration of $\mathrm{CH}_{2}$ [40-41]. This band is strong in crystalline cellulose and weak in amorphous cellulose [42]. So, higher crystalline cellulose obtained in 5 \& $10 \% \mathrm{H}_{2} \mathrm{SO}_{4}, 5 \% \mathrm{NaOH}$ and un-treated sugarcane bagasse when compared with the $10 \% \mathrm{NaOH}$ treated sample. On the other hand, cellulose in sugarcane bagasse became more amorphous after pretreatment using strong alkali treatment. It could be concluded that the amount of amorphous cellulose was highest in the sugarcane bagasse sample pretreated by $10 \% \mathrm{NaOH}$ followed by $5 \%, 10 \% \mathrm{H}_{2} \mathrm{SO}_{4}$ and $5 \% \mathrm{NaOH}$, respectively.

The peaks at 1,324, 1,514 and $1604 \mathrm{~cm}^{-1}$ were indicators of hemicelluloses and lignin characteristic [41, 43]. More specifically, $1,324 \mathrm{~cm}^{-1}$ peak reveals the aromatic hydroxyl groups generated by the cleavage of ether bonds within lignin, $1,514 \mathrm{~cm}^{-1}$ is associated with the aromatic skeletal modes of lignin whereas $1,604 \mathrm{~cm}^{-1}$ is stated to be stretching of the $C=C$ and $C=O$ lignin aromatic ring $[44,14,43,38]$. As observed in Fig. 1, bagasse samples subjected to acid pretreatment were delignified slightly for the peaks generated at $1,324,1,514$ and $1604 \mathrm{~cm}^{-1}$ were identical and that there was a subtle difference between the acid pretreated samples and the untreated one. However, peak disappear at 1,324, 1,514 and $1604 \mathrm{~cm}^{-1}$ when bagasse subjected to alkali pretreatment was delignified more efficiently in comparison with the acid pretreatments and un-treated sugarcane bagasse. Chandel et al., [14] and Zhang et al., [32] also reported similar results for sugarcane bagasse.

The FTIR analysis of bagasse further showed an aldehyde group absorption peak was clearly present at $1733 \mathrm{~cm}^{-1}$. This absorbance has been suggested to be due to acetyl groups in the lignin or hemicellulose structure [45]. It was observed that, the absorption peak at $1733 \mathrm{~cm}^{-1}$ was disappearance when the sugarcane bagasse treated with acid and alkali pretreatment. The relative absorbance of these two kinds of $\mathrm{CO}$ groups was reduced in the pretreated solid residues [14]. This reduction in the ketone and aldehyde groups may be due to degradation of the aliphatic chain of phenyl propane units in the lignin molecules. The absorbance by hydroxyl groups occurs in as a number of different bands.

The band at $3395 \mathrm{~cm}^{-1}(\mathrm{O}-\mathrm{H})$ was more intense in the acid pretreatment than in the alkaline pretreatment and in raw SB. A similarity in the bands at $2917 \mathrm{~cm}^{-1}$ could be observed for the raw material, acid and the alkaline pretreatment, but was more intense for the acid pretreatments. The $2917 \mathrm{~cm}^{-1}$ band represents $\mathrm{C}-\mathrm{H}$ and $\mathrm{CH}_{2}$ stretching, which is unaffected by changes in crystallinity [33]. The results indicated that the highly crystalline cellulose in SB was transformed to amorphous form after pretreatment. Overall as could be concluded from Fig. 1, using alkali pretreatments is a suitable method for removing lignin.

Figure 2 and Table 2 show the results of the X-ray diffraction analysis carried out to evaluate the crystallinity degree of the raw and pretreated bagasse. The X-ray diffraction (XRD) analysis of untreated bagasse, acid pretreated bagasse (cellulignin), and alkali pretreated cellulignin substrate is presented in Fig. 2a-e. Crystallinity is strongly influenced by the biomass composition. The intensities (1002) of the amorphous cellulose peak and crystalline cellulose peak were considered to calculate the Crystallinity 
Index (Crl) of all five samples of bagasse. The Crl of untreated bagasse was $49.67 \%$, which was close to a previously available report $[46,43]$. The $\mathrm{Crl}$ of acid and alkali pretreated sugarcane bagasse was comparatively lower than untreated sugarcane bagasse showing the sequential increment in cellulose content in these samples (Fig. 2b,c,d,e). Acid pretreatment of bagasse removed the hemicellulose, and thus increased the cellulose amount in samples eventually and showed lower $\mathrm{Crl}$ (35.7 and 33.97\%). Further, cellulignin when pretreated with alkali pretreatment ( $5 \%$ and $10 \% \mathrm{NaOH}$ at $121^{\circ} \mathrm{C}$ for $60 \mathrm{~min}$ ) showed lower $\mathrm{Crl}$ (41.1 and 11.2\%) because of the removal of lignin, and thus increased the cellulose concentration in bagasse than that of untreated bagasse and cellulignin. In other words, this sharp decrease in crystallinity due to the alkali pretreatment confirms that the regenerated products were highly amorphous and thus, cellulose surface accessibility and consequently the efficiency of enzymatic hydrolysis were considerably increased [12, 45, 41, 43].

Table 2

Crystallinity index of un-treated, acid and alkali pretreated sugarcane bagasse

\begin{tabular}{|lll|}
\hline S.N. & Pretreatment & $\begin{array}{c}\text { Crytallinity Index } \\
(\%)\end{array}$ \\
\hline 1 & Un-treated sugarcane bagasse & 49.67 \\
\hline 2 & $5 \%$ Sulphuric acid treated sugarcane bagasse at $121^{\circ} \mathrm{C}$ for $60 \mathrm{~min}$ & 35.7 \\
\hline 3 & $10 \%$ Sulphuric acid treated sugarcane bagasse at $121^{\circ} \mathrm{C}$ for $60 \mathrm{~min}$ & 33.97 \\
\hline 4 & $5 \%$ Sodium hydroxide treated sugarcane bagasse at $121^{\circ} \mathrm{C}$ for 60 min & 41.1 \\
\hline 5 & $\begin{array}{l}10 \% \text { Sodium hydroxide treated sugarcane bagasse at } 121^{\circ} \mathrm{C} \text { for } \\
60 \text { min }\end{array}$ & 11.2 \\
\hline Figure ligends & \\
\hline
\end{tabular}

Figure 3 presents the morphological structural changes obtained in sugarcane bagasse during the acid and alkaline pretreatment. SEM images of un-treated, acid and alkali pretreated bagasse samples were taken at different magnifications. Figures (3a) clearly indicates that the untreated bagasse had highly compact, ordered and rigid fibril morphology [32] when compare with acid and alkali pretreated bagasse samples (Fig. 3b-e). Several workers have been reported similar observation for un-treated and treated bagasse $[46,43]$. Sugarcane bagasse residue from alkali-pretreatment $\left(10 \% \mathrm{NaOH}\right.$ at $121^{\circ} \mathrm{C}$ for $\left.60 \mathrm{~min}\right)$ was the most severely disrupted followed by $5 \% \mathrm{NaOH}$ alkali, $10 \% \mathrm{H}_{2} \mathrm{SO}_{4}$ and $5 \% \mathrm{H}_{2} \mathrm{SO}_{4}$ acidpretreatments. The disruption of the residue surface might have been caused by the solvating action of the acid and alkali pretreatment [47]. Due to the partial removal of hemicelluloses and lignin, the surface of the bagasse with $\mathrm{NaOH}$ pretreatment became soft, loosened, and contained some micro-pores on the surface of the sugarcane bagasse (Fig. $3 \mathrm{~d}$ and e). From the figure it revealed that surface has become rough, puffy, loose and conglomerate textures and the native fibrous structure has been wholly distorted after the pretreatment by $10 \% \mathrm{NaOH}$ at $121^{\circ} \mathrm{C}$ for $60 \mathrm{~min}$. Acid (5\% and $10 \% \mathrm{H}_{2} \mathrm{SO}_{4}$ at $121^{\circ} \mathrm{C}$ for $60 \mathrm{~min}$ ) and alkali ( $5 \% \mathrm{NaOH}$ at $121{ }^{\circ} \mathrm{C}$ for $60 \mathrm{~min}$ ) pretreatments had similar effects on bagasse sample (Fig. 3be) and led to highest modifications in bagasse structure after $10 \%$ alkali pretreatment. Similarly, 
Fasanella et al., [16] also reported that when bagasse treated with $\mathrm{NaOH}$, it not only break the lignin structure, but also hydrate and swell the cellulose fibers, reducing crystallinity. Accessibility of the substrate to the cellulolytic enzymes is one of the major factors influencing the hydrolysis process [ 42 , $48,43]$. Previous study has illustrated that the cellulases can get trapped in the pores if the internal area is much larger than the external area $[49,50]$. Thus, one of the objectives of the pretreatment is to increase the porosity and available surface area for the enzymatic attack [51, 43, 32]. The morphological investigation in the present study showed a significant increase in the porosity and surface area after the pretreatment, thus contribute to the enhancement of subsequent enzymatic hydrolysis [37, 43, 32].

Cellulase and xylanase filtrate of Pseudomonas sp. CVB-10 and Bacillus paramycoides T4 was applied for enzymatic saccharification of pretreated bagasse sample. A maximum of $489.50 \mathrm{mg} / \mathrm{g}$ glucose was obtained from the base pretreated SB after 30 hours of enzymatic hydrolysis. Acid pretreated bagasse (cellulignin) showed only $322.75 \mathrm{~g} / \mathrm{l}$ sugars recovery proving the requirement of alkali mediated delignification (Fig. 4a-f). Chandel et al., [14] also reported that alkali pre-treated substrate showed maximum saccharification and reducing sugar production.

Enzymatic saccharification/hydrolysis of the raw and pretreated samples was affected by incubation period. Figure 4 a depicted that a highest saccharification was obtained from $10 \% \mathrm{NaOH}$ at $121^{\circ} \mathrm{C}$ when compared with other treatments. The content of reducing sugar was gradually decreased after $30 \mathrm{~h}$ of incubation. This might be due to the inhibition of the enzyme activity by the accumulated hydrolysis products.

Enzyme saccharification/hydrolysis also affected by different substrate concentration. From the result it clear that the maximum saccharification was achieved at $5 \%$ substrate concentration ( $10 \%$ alkali pretreated sugarcane bagasse) within optimized incubation time (Fig. 4b). Above and below of this substrate concentration, enzymatic saccharfication rate and hydrolysis rate were decreased gradually. Similarly, Gupta et al., [8] also reported that maximum reducing sugar production/saccharification was reported at $5 \%$ substrate concentration.

Temperature plays a key role in enzymatic reaction/saccharification of pretreated sugarcane bagasse samples. Generally, as the temperature is raised in a certain range, the enzymatic activity is accelerated. Enzyme catalyzed reaction like most chemical reactions; proceeds at a faster velocity as the temperature is increased. The optimal reaction temperature for cellulase and xylanase is between $45^{\circ} \mathrm{C}-55^{\circ} \mathrm{C}$. In this experiment, maximum saccharification rate was observed at $55^{\circ} \mathrm{C}$ from alkali pretreated sugarcane bagasse (10\%) (Fig. 4c). Lamounier et al., [26] also reported that maximum reducing sugar production during saccharification at $55^{\circ} \mathrm{C}$. Further increased temperature beyond $55^{\circ} \mathrm{C}$, the concentration of reducing sugar and saccharification rate were reduced. Thus, the optimal temperature for enzymatic saccharification/hydrolysis was $55^{\circ} \mathrm{C}$.

Initial pH conditions also influence enzymatic saccharification/hydrolysis. Maximum reducing sugars/saccharification was achieved at $\mathrm{pH} 5.0$ from alkali pretreated bagasse. When $\mathrm{pH}$ was increased or decreased than 5.0, the enzymatic reaction was reduced [15]. Initial pH Changes may result in the 
failure of cellulase and xylanase activity or dissociation may occur between substrate and active site of enzyme, the enzyme-catalyzed hydrolysis reaction to achieve maximal activity of enzyme $[52,15]$. For these reasons, enzymes are only active over a certain $\mathrm{pH}$ range.

Enzymatic saccharification/hydrolysis of pretreated bagasse is also influences by enzyme ration. The highest amount of reducing sugar $476.9 \mathrm{mg} / \mathrm{g}$ with maximum saccharification was obtained after $30 \mathrm{~h}$ reaction when enzyme ratio was at 3:1. It was then followed by the enzyme ratio 2:1, 1:3, 1:2 and 1:1. The findings illustrated that the enzyme ratio of 2:1 and 3:1 produced higher amounts of reducing sugar compared others. Similarly, Lai and Idris, [15] also reported that 5:1 ratio of cellulase: $\beta$-glucosidase showed maximum glucose production.

In this experiment different concentration (0.1-1.0\%) of tween-20 were optimized for maximum saccharification under all optimized conditions. Figures (4f) depicted that maximum $489.50 \mathrm{mg} / \mathrm{g}$ reducing sugar with maximum saccharification rate was achieved at $0.5 \%$ tween- 20 concentration. Above and below this concentration there is no significant result was reported from the surfactant. Surfactants generally enhance the surface area of lignocellulosic substrates to improve the extent of enzymatic hydrolysis. Non-ionic surfactant-like Tween 20 is more effective due to its adsorption on hydrophobic surfaces mainly composed of lignin fragments $[53,14]$.

\section{Conclusion}

Several things like the lignin and hemicelluloses composition, surface areas, crystallinity and degree of polymerization influence the effectiveness sugarcane bagasse decomposition by cellulases and xylanases. The main aim of acid and alkali pretreatment is to remove lignin and hemicelluloses content, reduce cellulose crystallinity and enhance the porosity. Hence, a suitable pretreatment method plays a key role in enhancing the competence of cellulose and hemicellulose hydrolysis. The acid and alkali pretreatment methods applied in this study effort to raise the substrates surface area, reduce the lignin and hemicellulase content and disorder the polymerization of sugarcane bagasse. Two different concentrations of acid and alkali were applied for pretreatment of sugarcane bagasse. Among different concentration of acid and alkali pretreatments studied, the $10 \% \mathrm{NaOH}$ pretreatment was found to be the most competent in lignin removal and led to the enhancement of the cellulose and hemicellulose content in pretreated sugarcane bagasse. This treatment technique recommends the opportunity of producing cellulosic material largely free from lignin, which ultimately would be a good substrate for bioethanol generation. However, there is a need to build up proficient biological delignification techniques to formulate the process eco-friendly. The FTIR, XRD and SEM analysis showed $10 \% \mathrm{NaOH}$ pretreatment followed by $10 \% \mathrm{H}_{2} \mathrm{SO}_{4}, 5 \% \mathrm{NaOH}$ and $5 \% \mathrm{H}_{2} \mathrm{SO}_{4}$ pretreatment as most efficient in terms of altering the morphology of sugarcane bagasse. Overall, $10 \% \mathrm{NaOH}$-pretreated sugarcane bagasse showed maximum saccharification/hydrolysis $498.5 \mathrm{mg} / \mathrm{g}$ reducing sugar after $30 \mathrm{~h}$, whereas hydrolysis of untreated sugarcane bagasse generated only $219.4 \mathrm{mg} / \mathrm{g}$ reducing sugar.

\section{Materials And Methods}




\section{Preparation of raw materials}

The raw substrate, sugarcane bagasse was collected locally, dried in a hot air oven at $50^{\circ} \mathrm{C}$ and then cut into small pieces. The dried material was ground and passed through a 20-40 mesh size screen using a laboratory knife mill (Metrex Scientific Instrumentation, Delhi, India). The processed substrate was thoroughly washed, dried at $60^{\circ} \mathrm{C}$ and stored in sealed plastic bags at room temperature for further experiments.

\section{Microorganism}

The strain of Pseudomonas sp. CVB-10 and Bacillus paramycoides T4, isolated from soil sample of different sites of Varanasi, was used in this study. The Pseudomonas sp. CVB-10 and Bacillus paramycoides $\mathrm{T} 4$ culture was maintained on carboxymethy cellulose $(\mathrm{CMC})$ and xylan agar slants at $4{ }^{\circ} \mathrm{C}$ and sub-cultured monthly.

\section{Inoculum preparation}

Mother culture was prepared by inoculating one full loop of $24 \mathrm{~h}$ grown culture of Pseudomonas sp. CVB10 [MK443365] and Bacillus paramycoides T4 [MN370035] on CMC and xylan agar plate in $50 \mathrm{ml}$ CMC broth and xylan broth, and incubated at $40{ }^{\circ} \mathrm{C}$ for overnight to achieve active exponential phase. Suitable amount of cell suspension were used to inoculate the test flasks.

\section{Enzyme Production}

The culture were grown in a $150 \mathrm{ml}$ Erlenmeyer flask that contain $50 \mathrm{ml}$ of basal medium containing $2.0 \%$ un-treated sugarcane bagasse and $0.5 \%$ ammonium sulphate for cellulase production and $1 \%$ birch wood xylan and $0.05 \%$ ammonium sulphate for xylanase production. The $\mathrm{pH}$ of the medium was adjusted to 5.5 prior to sterilization. The flasks were inoculated and incubated at $40^{\circ} \mathrm{C}$ for $48 \mathrm{~h}$. The crude enzyme was filtered and centrifuged at $10000 \mathrm{rpm}$ for $10 \mathrm{~min}$ and enzyme assay was carried out. Enzyme activity was measured by Nelson-Somogyi method [54-55]. One unit of enzyme activity is defined as $1 \mathrm{mg}$ of reducing end group (glucose) released per min at $40^{\circ} \mathrm{C}$.

\section{Sugarcane Bagasse Composition}

Cellulose, hemicellulose, lignin, ash, organic solvent extractives, and hot water extractives $\left(100{ }^{\circ} \mathrm{C}\right)$ contents were quantified in the raw material and in the solid fraction of the pretreated bagasse. The amounts of cellulose, hemicellulose, lignin and ashes were determined according to the methods described by Gouveia et al., [56]. Determinations of organic solvent and hot water extractives were carried out according to the NREL procedure (National Renewable Energy Laboratory, Golden, Colorado -USA) [57] with some modifications; quantification of hot water extractives (sugars, HMF, furfural and organics acids) was carried out by high performance liquid chromatography (HPLC). All characterizations were assayed in triplicate. 


\section{Pretreatments}

\section{Acid pretreatment}

The dilute $\mathrm{H}_{2} \mathrm{SO}_{4}$ (98\% purity) pretreatment of sugarcane bagasse substrate (10.0 g) was carried out using varied acid concentration ( 5 and $10 \%, \mathrm{w} / \mathrm{v}$ ) and incubation time (30 and $60 \mathrm{~min}$ ) at $121^{\circ} \mathrm{C}$, using a ratio of $1 / 10$ between the bagasse mass and the volume of acid solution. The hydrolysates after treatment were separated by filtering the contents through double layered muslin cloth. The residual biomass (cellulignin) was washed with tap water till neutral $\mathrm{pH}$ and dried in a hot air oven at $65^{\circ} \mathrm{C}$.

\section{Alkali pretreatment}

The sugarcane baggase $(10.0 \mathrm{~g})$ was presoaked in two different concentrations of $\mathrm{NaOH}$ ( $5 \%$ and $10 \%$, $\mathrm{w} / \mathrm{v}$ ) for $2 \mathrm{~h}$ and thereafter, thermally pretreated at $121^{\circ} \mathrm{C}$, using a ratio of $1 / 10$ between the sugarcane bagasse mass and the volume of alkali solution for 30 and $60 \mathrm{~min}$. The pretreated sample was filtered through double layered muslin cloth, washed extensively with tap water until neutral $\mathrm{pH}$ and dried at $65^{\circ} \mathrm{C}$.

\section{Structural characterization}

\section{Fourier transform infrared spectroscopy (FTIR) analysis}

The chemical structures of untreated and pretreated sugarcane bagasse (acid and alkali) were characterized by FTIR (Thermo electron scientific instruments LLC, USA). All solid samples were dried and then pressed into a disc with $\mathrm{KBr}$. The samples ( $\mathrm{KBr}$ pellets) for analyses were prepared by mixing $2 \mathrm{mg}$ material powder with $200 \mathrm{mg} \mathrm{KBr}$. The discs used in this work were thin enough to obey the BeerLambert law. Infrared spectra were obtained using a Nicolet iS5 FTIR spectrometer with thirty two scans alongwith resolution of $4 \mathrm{~cm}^{-1}$ in the range of $400 \mathrm{~cm}^{-1}$ and $4000 \mathrm{~cm}^{-1}$. Thus, it was possible to detect the changes caused by the pretreatments in relation to the content of lignin and hemicellulose.

\section{X-ray diffraction (XRD)}

The crystalline nature of untreated and pretreated sugarcane bagasse samples (Acid and Alkali) was analyzed by using a Rigaku Smart Lab 9 kW Powder type (without $\chi$ cradle) HR-XRD using monochromatic CuKa radiation ( $1.54 \AA$ ) set at $40 \mathrm{KV}, 30 \mathrm{~mA}$. The goniometer scanned a $2 \theta$ range between $5^{\circ}$ and $70^{\circ}$ at a $5^{\circ} / \mathrm{min}$ scanning rate. Samples were scanned over the range of $100<2 \theta<500$ with a step size of $0.05^{\circ}$ and the Crl was determined using the empirical method proposed by Segal et al., [58]. Samples were measured in duplicates and the average values of the $\mathrm{Crl}$ was obtained from the relationship between the intensity of the 002 peak for cellulose I $\left(I_{002}\right)$ and the minimum dip $\left(I_{a m}\right)$ between the 002 and the 101 peaks, following the formula:

$\mathrm{Crl}=\mathrm{I}_{002}-\mathrm{I}_{\text {amorphous }}$ 
In which, 1002 is the intensity for crystalline portion of biomass at about $2 \mathrm{~h}=22.5$ and $\mathrm{I}_{\mathrm{am}}$ is the peak for the amorphous portion (i.e., cellulose, hemicelluloses and lignin) at about $2 \mathrm{~h}=16.6$. The second highest peak after $2 \mathrm{~h}=22.5$ was $2 \mathrm{~h}=16.6$, and was assumed to correspond to amorphous region [59].

\section{Scanning electron microscopy}

Scanning electron microscopy (SEM) was used to observe the morphology of the raw and pretreated sugarcane bagasse to evaluate the changes in the external structure caused by the pretreatments (EVO 18 Research ZEISS, UK). SEM was carried out using a voltage of $10 \mathrm{kV}$ and working distance of $10 \mathrm{~mm}$, spot size of 4.0, SE detector and metallizer (EVO 18 Research ZEISS, UK). Before the determination, samples were mounted with conductive glue and coated with a thin layer of gold to improve the conductivity and the quality of the SEM images. Finally, many spots (at least five) were considered for each sample under different magnifications.

\section{Enzymatic saccharification}

The pretreated sugarcane bagasse samples were hydrolyzed using condensed enzyme. The hydrolysis reaction was performed in $0.1 \mathrm{M}$ citrate buffer $(\mathrm{pH} 5.0)$ at $50{ }^{\circ} \mathrm{C}$ for $96 \mathrm{~h}$ with shaking (150 rpm). The substrate with buffer was pre-incubated at $50{ }^{\circ} \mathrm{C}$ on a orbit shaker incubator (RC5100 SELEC, NEOLAB, orbit shaker incubator, Germany) at $150 \mathrm{rpm}$ for $2 \mathrm{~h}$ and thereafter the slurry was added with cellulases and xylanases enzymes produced by isolated bacterial culture Pseudomonas sp. CVB-10 and Bacillus paramycoides T4. Tween-20 $(0.1 \%, \mathrm{v} / \mathrm{v})$ was also added to the reaction mixture and the reaction continued up to $48 \mathrm{~h}$. Samples of enzymatic hydrolysate were withdrawn at regular intervals and analyzed for amount of glucose released by Nelson [54] and Somogi [55] methods. The effects of different factors e.g., pretreatment reaction time (6-48 h), substrate concentration $(1-10 \% \mathrm{w} / \mathrm{v})$, temperature $\left(40-60{ }^{\circ} \mathrm{C}\right), \mathrm{pH}(4.0-6.0)$, substrate enzyme ratio $(1: 1,1: 2,1: 3,2: 1,3: 1)$ and Tween-20 concentration $(0.1-1.0 \%)$ on the enzymatic hydrolysis was determined by maintaining the enzyme/substrate ratio at $25 \mathrm{FPU} / \mathrm{g}$. All enzyme saccharification experiments were performed in triplicates.

\section{Statistical analysis}

All the experiments were performed in triplicate and the results are presented as mean \pm standard deviation.

\section{Abbreviations}

FTIR

Fourier transforms infrared; XRD:X-RAY Diffraction; SEM:Scanning electron microscopy; HMF:Hydroxymethylfurfural; HPLC:High Performance Liquid Chromatography; CMC:Carboxymethy Cellulose; KBr:Potassium Brimide; Crl:Crystalline Index 


\section{Declarations}

\section{Ethics approval and consent to participate}

This article does not contain any studies with human participants or animals performed by any of the authors.

\section{Consent for publication}

All authors consent to publish this manuscript.

\section{Availability of data and materials}

Name of the repository is NCBI (National Center for Biotechnology Information) where our data's were deposited and a link to the dataset DOI are https://www.ncbi.nlm.nih.gov/nucleotide/MK443365.1 and https://www.ncbi.nlm.nih.gov/nuccore/MN370035.1.

\section{Competing interests}

The author(s) declare that they have no competing interests.

\section{Funding}

This work was supported by the University Grant Commission Delhi, India [F-4-2/2006(BSR)/BL/1718/0049]. The funding bodies played no role in the design of the study or in collection, analysis, or interpretation of data, or in writing the manuscript.

\section{Authors' contributions}

1. S. T. carried out the research work and drafted the manuscript.

2. J. Y. and R. G. has designed the experiment, contributed substantially to analysis and interpretation of data and have given final approval of the version to be published.

3. J.S.Y. performed the Molecular characterization of the isolates and the data analysis.

All authors read and approved the final manuscript.

\section{Acknowledgement}

Dr. D.S. Kothari PDF Fellow is greatly acknowledged by all Authors.

\section{Supplementary information}

The supporting data also include in this manuscript as a supporting file.

\section{Permission to collect sample}


No permission was necessary to collect samples.

\section{Authors Detail}

${ }^{1 *}$ Department of Soil Sciences and Agricultural chemistry Institute of Agricultural Sciences BHU, Varanasi-221005, ${ }^{2}$ Department of Microbiology (Centre of Excellence), Dr. Ram Manohar Lohia Avadh University, Faizabad- 224001, Uttar Pradesh, India, ${ }^{3}$ Department of Botany, Institute of Sciences Banaras Hindu Uinversity, Varanasi-221005

\section{References}

1. Hofsetz K, Silva MA. Brazilian sugarcane bagasse: Energy and non-energy consumption. Biomass Bioener. 2012;46:564-73.

2. Quintero JA, Montoya MI, Sánchez OJ, Giraldo OH, Cardona CA. Fuel ethanol production from sugarcane and corn: comparative analysis for a Colombian case. Energy. 2008;33:385-99.

3. Demirbas MF. Biorefineries for biofuel upgrading: a critical review. Appl Ener. 2009;86:151-61.

4. Balat $\mathrm{M}$, Balat $\mathrm{H}$. Recent trends in global production and utilization of bioethanol fuel. Appl Ener. 2009;86:2273-82.

5. Demirbas A. Competitive liquid biofuels from biomass. Appl Ener. 2011;88:17-28.

6. Pandey A, Soccol CR, Nigam P, Soccol VT. Biotechnological potential of agroindustrial residues. I. Sugarcane bagasse. Bioresour Technol. 2000;74:69-80.

7. Richardson S, Gorton L. Characterisation of the substituent distribution in starch and cellulose derivatives. Anal Chim Acta. 2003;497:27-65.

8. Gupta R, Khasa YP, Kuhad RC. Evaluation of pretreatment methods in improving the enzymatic saccharification of cellulosic materials. Carbohyd Polym. 2011;84:1103-9.

9. Ko JK, Um Y, Woo HM, Kim KH, Lee S-M. Ethanol production from lignocellulosic hydrolysates using engineered Saccharomyces cerevisiae harboring xylose isomerase-based pathway. Bioresour Technol. 2016;209:290-6.

10. Costa CE, Romaní A, Cunha JT, Johansson B, Domingues L. Integrated approach for selecting efficient Saccharomyces cerevisiae for industrial lignocellulosic fermentations: Importance of yeast chassis linked to process conditions. Bioresour Technol. 2017;227:24-34.

11. Zhao X, Zhang L, Liu D. Comparative study on chemical pretreatment methods for improving enzymatic digestibility of Crofton weed stem. Biores Technol. 2008;99:3729-36.

12. Mosier N, Wyman C, Dale B, Elander R, Lee YY, Holtzapple M, et al. Features of promising technologies for pretreatment of lignocellulose biomass. Bioresour Technol. 2005;99:673-86.

13. Gupta R, Mehta G, Khasa YP, Kuhad RC. Fungal delignification of lignocellulosic biomass improves the saccharification of cellulosics. Biodegradation. 2010. doi:10.1007/s10532-010-9404-6. 
14. Chandel AK, Antunes FAF, Anjos V, Bell MJV, Rodrigues LN, Polikarpov I, de Azevedo ER, Bernardinelli OD, Rosa CA, Pagnocca FC, da Silva SS. Multi-scale structural and chemical analysis of sugarcane bagasse in the process of sequential acid-base pretreatment and ethanol production by Scheffersomyces shehatae and Saccharomyces cerevisiae. Biotechnol Biofuels. 2014;7:63.

15. Lai LW, Idris A. Comparison of steam-alkali-chemical and microwave-alkali pretreatment for enhancing the enzymatic saccharification of oil palm trunk. Renewable Ener. 2016;99:738-46.

16. Fasanella CC, Montes CR, Rossi ML, Aguiar MM, Ferreira LFR, Pupo MMS, Salazar-Banda GR, Monteiro R. Microscopic Analysis Of Sugarcane Bagasse Following Chemical And Fungal Treatment. Cellulose Chem Technol. 2018;52(1-2):59-64.

17. Chang V, Burrm B, Holtzapple M. Lime pretreatment of switchgrass. Appl Biochem Biotechnol. 1997;63-65:3-19.

18. Brigida AIS, Calado VMA, Gonçalves LRB, Coelho MAZ. Effect of chemical treatments on properties of green coconut fiber. Carbohyd Polym. 2010;79:832-8.

19. Zhao X, Zhou Y, Zheng G, Liu D. Microwave pretreatment of substrates for cellulase production by solid-state fermentation. Applied Biochem Biotechnol. 2010;160:1557-71.

20. Camargo FA, Innocentini-Mei LH, Lemes AP, Moraes SG, Duran N. Processing and characterization of composites of poly(3-hydroxybutyrateco-hydroxyvalerate) and lignin from sugar cane bagasse. $\mathrm{J}$ Composite Materials. 2012;46:417-25.

21. Rocha MVP. Produção de Bioetanol a partir de Pedúnculo de Caju (Anacardium occidentale L.) por Fermentação Submersa. Ph.D. Thesis, Universidade Federal do Rio Grande do Norte (In Portuguese), 2010.

22. Ladeira-Ázar RIS, Morgan T, Maitan-Alfenas GP, Guimarães VM. Inhibitors Compounds on Sugarcane Bagasse Saccharification: Effects of Pretreatment Methods and Alternatives to Decrease Inhibition. Appl Biochem Biotechnol. 2018. https://doi.org/10.1007/s12010-018-2900-6.

23. Shi T, Lin J, Li J, Zhang Y, Jiang C, Lv X, Fan Z, Xiao W, Xu Y, Liu Z. Pre-treatment of sugarcane bagasse with aqueous ammonia-glycerol mixtures to enhance enzymatic saccharification and recovery of ammonia. Bioresour Technol. 2019;289:1216-28.

24. $10.1155 / 2012 / 989572$

Canilha L, Chandel AK, dos Santos Milessi TS, Antunes FAF, da Costa Freitas WL, das Graças Almeida Felipe M, da Silva SS. Bioconversion of Sugarcane Biomass into Ethanol: An Overview about Composition, Pretreatment Methods, Detoxification of Hydrolysates, Enzymatic Saccharification, and Ethanol Fermentation. J Biomedicine and Biotechnol. 2012; 2012:15. http://dx.doi.org/10.1155/2012/989572.

25. Moretti MMDS, Bocchini-Martins DA, Nunes CDCC, Vilhena MA, Perrone OM, DaSilva R, Boscolo M, Gomes E. Pretreatment of sugarcane bagasse with microwaves irradiation and its effects on the structure and on enzymatic hydrolysis. Appl Ener. 2014;122:189. 95.[32].

26. Lamounier KFR, Rodrigues PO, Pasquini D, Baffi MA. Saccharification of Sugarcane Bagasse Using an Enzymatic Extract Produced by Aspergillus fumigatus. J Renewable Mat. 2018; 6(2). 
27. Nakagame S, Chandra RP, Kadla JF, Saddler JN. The isolation, characterization and effect of lignin isolated from steam pretreated Douglas-fir on the enzymatic hydrolysis of cellulose. Bioresour Technol. 2011;102(6):4507-517.

28. Carvalheiro F, Duarte LC, Girio FM. Hemicellulose biorefineries: a review on biomass pretreatments. J Sci Indus Res. 2008;67:849-64.

29. Falkoski DL, Guimaraes VM, de Almeida MN, Alfenas AC, Colodette JL, de Rezende ST. Chrysoporthe cubensis: a new source of cellulases and hemicellulases to application in biomass saccharification processes. Bioresour Technol. 2013;130:296-305.

30. Harrison MD, Zhang Z, Shand K, Hara IMO, Doherty WOS, Dale JL. Effect of pretreatment on saccharification of sugar cane bagasse by complex and simple enzyme mixtures. Bioresour Technol. 2013;148:105-13.

31. Pandey KK, Pitman AJ. FTIR studies of the changes in wood chemistry following decay by brown-rot and white-rot fungi. Inter J Biodetio Biodegrad. 2003;52:151-60.

32. Zhang H, Huang S, Wei W, Zhang J, Xie J. Investigation of alkaline hydrogen peroxide pretreatment and Tween 80 to enhance enzymatic hydrolysis of sugarcane bagasse. Biotechnol Biofuels. 2019;12:107.

33. Nelson ML, O'Connor RT. Relation of certain infrared bands to cellulose crystallinity and crystal lattice type. Part II. A new infrared ratio for estimation of crystallinity in cellulose I and II. J Appl Polymer Sci. 1964;8:1325-41.

34. Guo G-L, Hsu D-C, Chen W-H, Chen W-H, Hwang W-S. Characterization of enzymatic saccharification for acid-pretreated lignocellulosic materials with different lignin composition. Enzy Microbial Technol. 2009;45:80-7.

35. Guilherme AA, Dantas PVF, Santos ES, Fernandes FAN, Macedo GR. Evaluation of composition, characterization and enzymatic hydrolysis of pretreated sugar cane bagasse. Brazil J Chem Engineer. 2015;32(1):23-33.

36. Labbe N, Rials TG, Kelley SS, Cheng ZM, Kim JY, Li Y. FT-IR imaging and pyrolysis-molecular beam mass spectrometry: new tools to investigate wood tissues. Wood Sci Technol. 2005;39:61-77.

37. Remli NAM, Md Shah UK, Mohamad R, Abd Aziz S. Effects of chemical and thermal pretreatments on the enzymatic saccharification of rice straw for sugars production. BioResources. 2014;1:510-22.

38. Karthika K, Arun AB, Melo JS, Mittal KC, Kumar M, Rekha PD. Hydrolysis of acid and alkali presoaked lignocellulosic biomass exposed to electron beam irradiation. Biores Technol. 2013;129:646-49.

39. Qing Q, Hu R, He Y, Zhang Y, Wang L. Investigation of a novel acid-catalyzed ionic liquid pretreatment method to improve biomass enzymatic hydrolysis conversion. Appl Microbiol Biotechnol. 2014. DOI 10.1007/s00253-014-5664-0.

40. Han L, Feng J, Zhang S, Ma Z, Wang Y, Zhang X. Alkali pretreated of wheat straw and its enzymatic hydrolysis. Brazilian J Microbiol. 2012; 53-61.

41. Mood SH, Golfeshan AH, Tabatabaei M, Abbasalizadeh S, Ardjmand M. Comparison of different ionic liquids pretreatment for barley straw enzymatic saccharification. 3 Biotech. 2013. DOI 
10.1007/s13205-013-0157-x.

42. Bian J, Peng F, Peng X-P, Xiao X, Peng P, Xu F, Sun R-C. Effect of [Emim]Ac pretreatment on the structure and enzymatic hydrolysis of sugarcane bagasse cellulose. Carbohyd Polym. 2014;100:211-7.

43. Lv X, Lin J, Luo L, Zhang D, Lei S, Xiao W, Xu Y, Gong Y, Liu Z. Enhanced enzymatic saccharification of sugarcane bagasse pretreated by sodium methoxide with glycerol. Bioresour Technol. 2018;249:226-33.

44. Hsu T, Guo G, Chen W, Hwang W. Effect of dilute acid pretreatment of rice straw on structural properties and enzymatic hydrolysis. Bioresour Technol. 2010;101:4907-913.

45. Yoon LW, Ngoh GC, Chua ASM, Hashim MA. Comparison of ionic liquid, acid and alkali pretreatments for sugarcane bagasse enzymatic saccharification. J Chem Technol Biotechnol. 2011;86:1342-48.

46. Bi S, Peng L, Chen K, Zhu Z. Enhanced enzymatic saccharification of sugarcane bagasse pretreated by combining $\mathrm{O}_{2}$ and $\mathrm{NaOH}$. Bioresour Technol. 2016;214:692-9.

47. Ang TN, Ngoh GC, Chua ASM, Lee MG. Elucidation of the effect of ionic liquid pretreatment on rice husk via structural analyses. Biotechnol Biofuels. 2012;5:67.

48. Sun FF, Zhao X, Hong J, Tang Y, Wang L, Sun H, Li X, Hu J. Industrially relevant hydrolyzability and fermentability of sugarcane bagasse improved effectively by glycerol organosolv pretreatment. Biotechnol Biofuels. 2016;9:59.

49. Zhang YH, Lynd LR. Toward an aggregated understanding of enzymatic hydrolysis of cellulose: Noncomplexed cellulase systems. Biotechnol Bioengineer. 2004;88:797-824.

50. Cao W, Sun C, Liu R, Yin R, Wu X. Comparison of the effects of five pretreatment methods on enhancing the enzymatic digestibility and ethanol production from sweet sorghum bagasse. Bioresour Technol. 2012;111:215-21.

51. Corrales RCNR, Mendes FMT, Perrone CC, Anna CS, de Souza W, Abud Y, da Silva Bon EP. FerreiraLeitão V. Structural evaluation of sugar cane bagasse steam pretreated in the presence of $\mathrm{CO}_{2}$ and $\mathrm{SO}_{2}$. Biotechnol Biofuels. 2012;5:36.

52. Shuler ML, Kargi F. Bioprocess Engineering: Basic Concepts. second ed. New Jersey: Prentice Hall; 1992.

53. Santos VTO, Esteves PJ, Milagres AMF, Carvalho W. Characterization of commercial cellulases and their use in the saccharification of a sugarcane bagasse sample pretreated with dilute sulfuric acid. $J$ Indus Microbiol Biotechnol. 2011;38:1089-98.

54. Nelson N. A photometric adaptation of the Somogyi method for the determination of glucose. J Biol Chem. 1944;153:375-80.

55. Somogyi M. Notes on sugar determination. J Biol Chem. 1952;195:19-23.

56. Gouveia ER, Nascimento RT, Souto-Maior AM, Rocha GJM. Validação de metodologia para a caracterização química de bagaço de canade-açúcar. Quim Nova. 2009;32:1500-3. 
57. Sluiter A, Ruiz R, Scarlata C, Sluiter L, Templeton D. Determination of Extractives in Biomass. Laboratory Analytical Procedure (LAP). Technical Report, NREL, 2008; p. 12.

58. Segal L, Creely JJ Jr, Martin AE, Conrad CM. An empirical method for estimating the degree of crystallinity of native cellulose using the X-ray diffractometer. Textile Res J. 1959;29:786-94.

59. Kumar R, Mago G, Balan V, Wyman CE. Physical and chemical characterizations of corn stover and poplar solids resulting from leading pretreatment technologies. Bioresour Technol. 2009;100:394862.

\section{Figures}
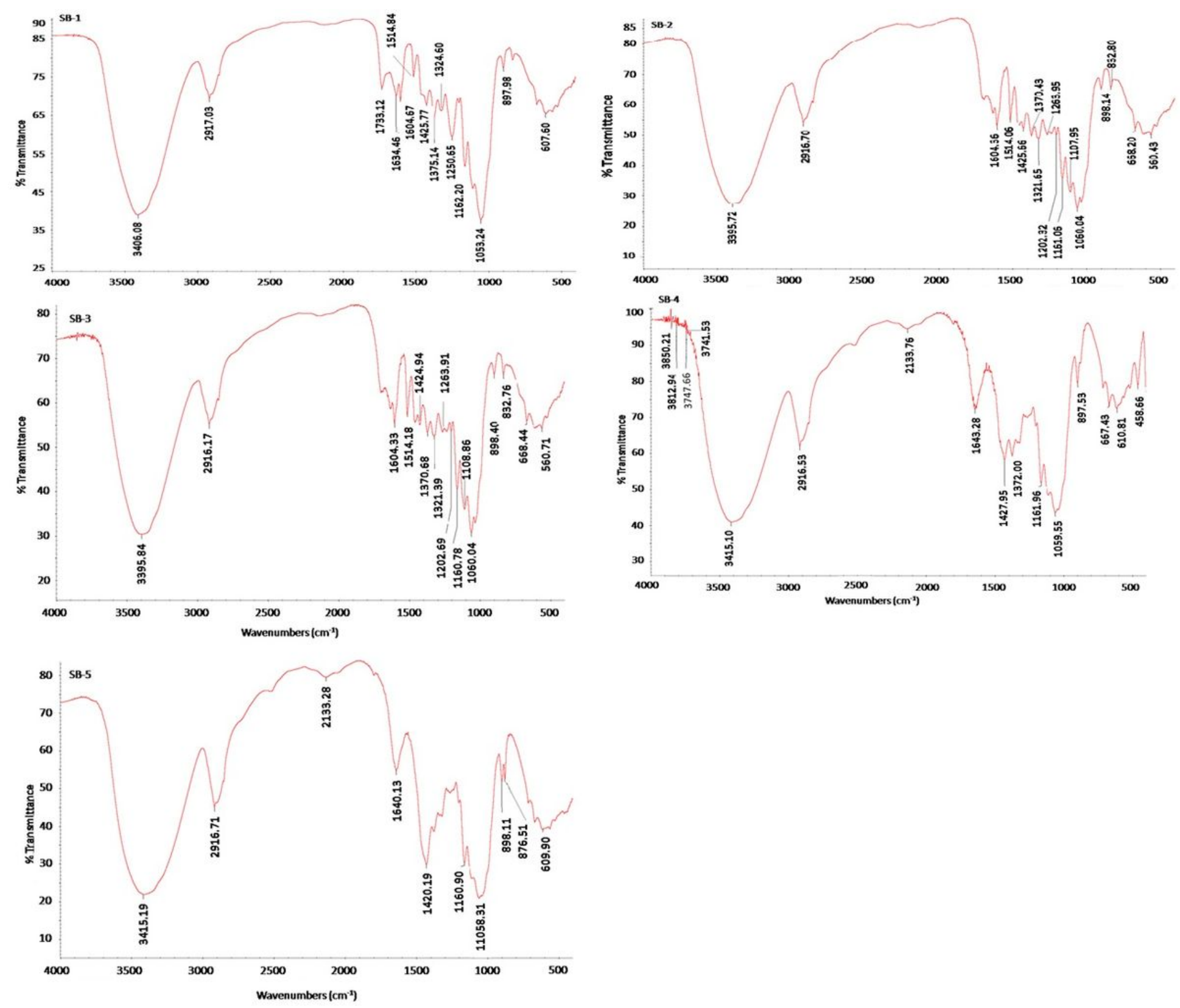

Figure 1 
Fourier transform infrared (FTIR) spectra of un-treated, acid and alkali pretreated sugarcane bagasse (SB). (a) Untreated sugarcane bagasse, (b) $5 \%$ sulfuric acid pretreated bagasse at $121 \mathrm{C}$ for $60 \mathrm{~min}$, (c) $10 \%$ sulfuric acid pretreated bagasse at $121^{\circ} \mathrm{C}$ for $60 \mathrm{~min}$ (d) $5 \%$ Sodium hydroxide pretreated bagasse at $121^{\circ} \mathrm{C}$ for $60 \mathrm{~min}(\mathrm{e}) 10 \%$ sodium hydroxide pretreated bagasse at $121^{\circ} \mathrm{C}$ for $60 \mathrm{~min}$.
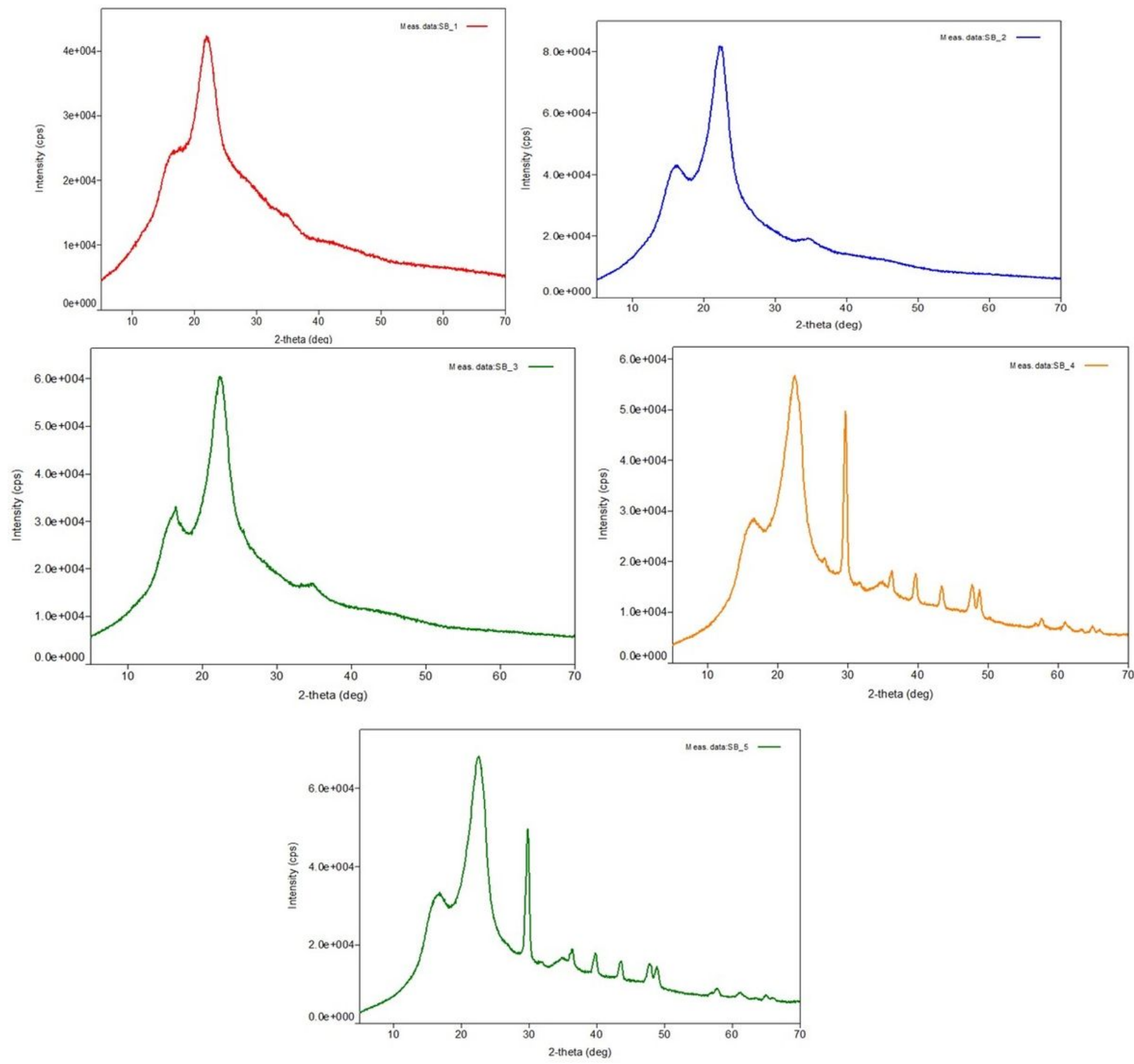

\section{Figure 2}

X-ray diffraction (XRD) pattern of native, acid and alkali pretreated sugarcane bagasse (SB). The crystallinity index ( $\mathrm{Crl}$ ) was found to be increased in cellulignin and $\mathrm{NaOH}$ pretreated bagasse. Enzymatic hydrolyzed SB showed the Crl value of cellulignin and $\mathrm{NaOH}$ treated bagasse. (a) Untreated sugarcane bagasse, (b) $5 \%$ sulfuric acid pretreated bagasse at $121^{\circ} \mathrm{C}$ for $60 \mathrm{~min}$, (c) $10 \%$ sulfuric acid pretreated 
bagasse at $121^{\circ} \mathrm{C}$ for $60 \mathrm{~min}$ (d) $5 \%$ Sodium hydroxide pretreated bagasse at $121^{\circ} \mathrm{C}$ for $60 \mathrm{~min}$ (e) $10 \%$ sodium hydroxide pretreated bagasse at $121^{\circ} \mathrm{C}$ for $60 \mathrm{~min}$. $\mathrm{Crl}$, crystallinity index; SB, sugarcane bagasse; $\mathrm{XRD}, \mathrm{X}$-ray diffraction.
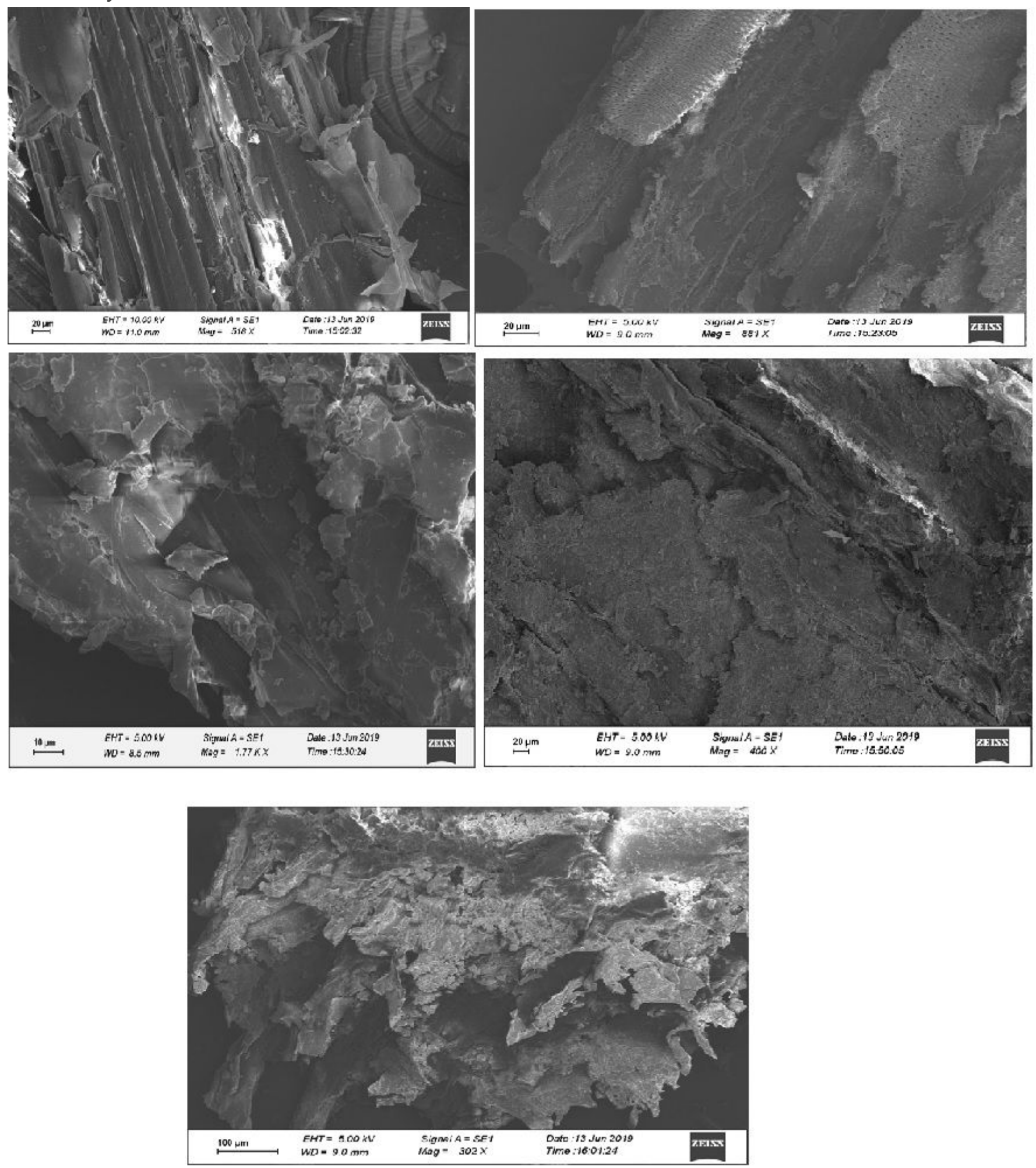

\section{Figure 3}

Scanning electron microscopic (SEM) analysis of sugarcane bagasse (SB). Showing surface image of (SB-1) natural, (SB-2) $10 \%$ sulfuric acid pretreated at $121^{\circ} \mathrm{C}$ for $30 \mathrm{~min}$, (SB-3) $10 \%$ sulfuric acid pretreated 
at $121^{\circ} \mathrm{C}$ for $60 \mathrm{~min}(\mathrm{SB}-4) 10 \%$ sodium hydroxide pretreated at $121^{\circ} \mathrm{C}$ for $30 \mathrm{~min}$, and (SB-4) $10 \%$ sodium hydroxide pretreated at $121^{\circ} \mathrm{C}$ for $60 \mathrm{~min}$.
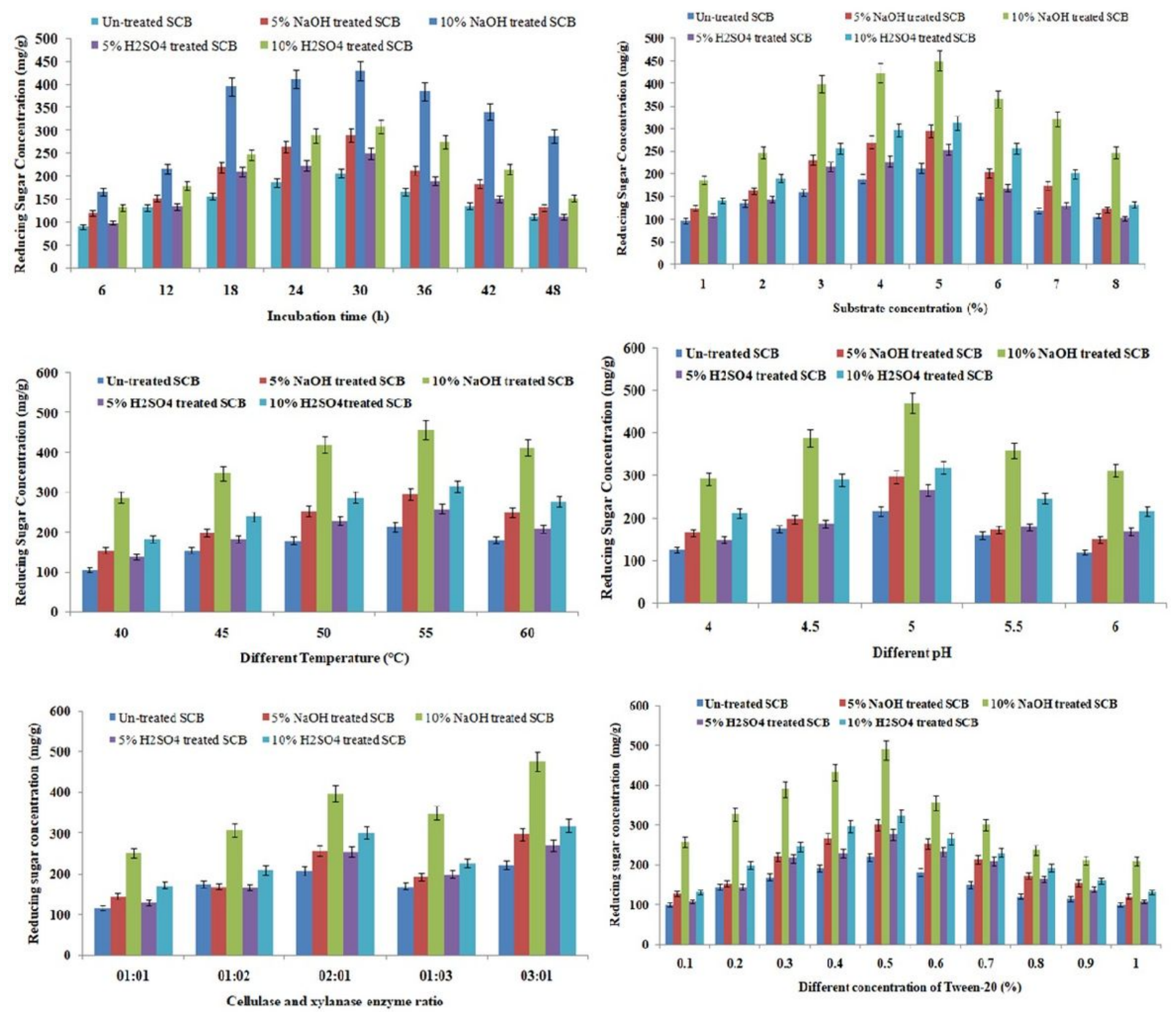

\section{Figure 4}

Reducing sugars yield of un-treated, acid (5 and $10 \% \mathrm{H} 2 \mathrm{SO} 4$ at $121^{\circ} \mathrm{C}$ for $60 \mathrm{~min}$ ) and alkali (5 and $10 \%$ $\mathrm{NaOH}$ at $121^{\circ} \mathrm{C}$ for $60 \mathrm{~min}$ ) pretreated SCB (Sugarcane bagasse) after enzymatic hydrolysis. The hydrolysis was carried out using Pseudomonas sp. CVB-10 and Bacillus paramycoides T4 enzymes (cellulase and xylanase) with an enzyme load of $25 \mathrm{FPU} / \mathrm{g}$. (a) The effect of different time incubation on enzymatic hydrolysis at $55^{\circ} \mathrm{C}, \mathrm{pH} 5.0$ and $2 \%$ substrate concentration. (b) The effect of different substrate concentration on enzymatic hydrolysis at $55^{\circ} \mathrm{C}, \mathrm{pH} 5.0$ for $30 \mathrm{~h}$ (c) The effect of different temperature on enzymatic hydrolysis at $\mathrm{pH} 5.0,5 \%$ substrate concentration for $30 \mathrm{~h}$ (d) The effect of different $\mathrm{pH}$ on enzymatic hydrolysis at $55^{\circ} \mathrm{C}, 5 \%$ substrate concentration for $30 \mathrm{~h}(\mathrm{e})$ The effect of different enzyme ratio 
on enzymatic hydrolysis at $55^{\circ} \mathrm{C}, \mathrm{pH} 5.0$, and $5 \%$ substrate concentration for $30 \mathrm{~h}$ (f) The effect of different concentration of Tween-20 on enzymatic hydrolysis at $55^{\circ} \mathrm{C}, \mathrm{pH} 5.0,5 \%$ substrate concentration and 3:1 enzymes concentration for $30 \mathrm{~h}$

\section{Supplementary Files}

This is a list of supplementary files associated with this preprint. Click to download.

- Additionalfile.docx 